\title{
Application of the Hierarchy Analysis Method at the Foodstuffs Quality Evaluation
}

\author{
Marina A. Nikitina ${ }^{1}$ \\ Center of Economic and Analytical Research and \\ Information Technologies \\ V.M. Gorbatov Federal Research Center for Food Systems \\ of Russian Academy of Sciences, Russia \\ Igor A. Nikitin², \\ Natalya G. Semenkina ${ }^{3}$ \\ Department "Technology of Grain Processing, Bakery, \\ Pasta and Confectionery Industries" \\ K.G. Razumovsky Moscow State University of \\ Technologies and Management \\ (The First Cossack University), Russia
}

\author{
Igor V. Zavalishin ${ }^{4}$ \\ Department "Rectorate" \\ K.G. Razumovsky Moscow State University of \\ Technologies and Management \\ (The First Cossack University), Russia
}

\author{
Andrey V. Goncharov 5 \\ Department "Automation and Control in Technical \\ Systems" \\ K.G. Razumovsky Moscow State University of \\ Technologies and Management \\ (The First Cossack University), Russia
}

\begin{abstract}
In Russia as well as in the other countries of the world national programs are implemented to improve the health of the population. An integral part of those programs are measures of improvement of food processes structure as well as the quality of food itself. New types of functional and specialized food products that meet the physiological needs of specific groups of the population with a therapeutic and therapeuticprophylactic action spectrum are becoming more widespread. The article proposes the concept of determining the quality of food products through the indicator of "effective functionality" on the basis of a multicriteria approach using the hierarchy analysis method. On the example of gluten-free flour confectionery products, the determination of the organoleptic evaluation of the quality of a food product is shown, as a particular solution for finding one of the complex indicators of the first level. The use of T. Saaty's method in making technological decisions on a large number of criteria is substantiated. The analysis of the obtained data allows to draw a conclusion that the greatest weight among alternatives was possessed by the sample containing three kinds of flour: buckwheat, amaranth and linen in the ratio 60:30:10.
\end{abstract}

Keywords-Effective functionality; hierarchy analysis method; gluten-free flour confectionery products; organoleptic evaluation of the quality; food product quality

\section{INTRODUCTION}

Health of the population is the most important indicator of the well-being of the nation. The constant impact on the population of various environmental factors in combination with psychoemotional loads leads to a decrease in the adaptive capacity of the human body. Today the number of alimentarydependent diseases continues to increase the leading position among which is occupied by diseases of the digestive system. The leading role in the prevention and treatment of these diseases belongs to metabolic therapy, which is based on diet therapy. The trerapy considered now as one of the most important adaptation-protective factors that promote the maintenance of good health, normal growth and development of the organism, preservation of working capacity and adaptation of the organism to adverse environmental factors [1].

The problem of nutrition correction is also relevant for Russia. The policy of the state is aimed at solving the problems connected with the organization of healthy nutrition of the population. "The fundamentals of the state policy in the area of healthy nutrition of the population of the Russian Federation for the period until 2020" define the increase of production of specialized products including flour confectionery as a priority task.

Nowadays the production of food products free of certain ingredients is rapidly developing, because these ingredients can be not recommended for certain medical indications (allergens, some types of proteins, oligosaccharides, polysaccharides, etc.). Taking into account the successes of nutrigenomics and nutrigenetics the trend towards the personalization of diets will increase and as a result contribute to an increase in the volume of the market for functional and specialized food products [2], [3]. The first key direction in the development of such products is a scientifically based selection of functional food ingredients with the required sanitary and hygienic, medical and biological indicators, therapeutic and prophylactic properties. And the second key direction is the development of new technological solutions that allow not only to influence the organoleptic and physicochemical parameters of raw materials and finished products increasing their nutritional value, but also to give them directed functional properties [4], [5].

An objective assessment of the increase in nutritional value and the imparting of functional properties to the finished product should be based on the principles of qualimetry. 
For a more effective description of the evaluation characteristic and the possibility of comparing different functional and specialized products it is advisable to introduce a quantitative indicator of functionality that will allow to speak about the "effective functionality" of a food product and to determine it in a dimensionless quantity called the generalized complex efficiency index of the top (or zero) level $\mathrm{K}_{0}$.

The structure of the complex indicator is considered by the authors as a multilevel hierarchical set of properties, among which it is necessary to single out such basic indicators of the first level such as the chemical composition, organoleptic characteristics, physical and chemical properties, safety indicators and microbiological indicators as well as cost.

The scheme of this approach is shown in Fig. 1.

In addition to finding a complex zero-level indicator this scheme involves the definition of first-level indicators as the finding of particular solutions in assessing the quality of food. For example, safety indicators, microbiological indicators or organoleptic characteristics of a product can also be determined using this scheme and the hierarchy analysis method and implemented at a selection of the optimal formulation of the final product.

The purpose of this paper is to demonstrate the use of the hierarchy analysis method of T. Saaty to make decisions in the field of a limited study - research and management in assessing the quality of products of the food industry.

On the example of a specialized food product (gluten-free gingerbread, which contains non-traditional types of raw materials), a definition of the organoleptic evaluation of product quality is shown as a particular solution for finding one of the complex indicators of the first level.

\section{OBJECTS AND METHODS OF RESEARCH}

The research was carried out at the laboratory of the "Technology of processing grain, bakery, macaroni and confectionery productions" chair of the K.G. Razumovsky Moscow State University of technologies and management (the First Cossack University) in conjunction with the Information Technology Department of the Center for Economic and Analytical Research and Information Technologies of the "Federal State Research Institution of V.M. Gorbatov" of the Russian Academy of Sciences.

The object of the study was model samples of brewed gluten-free gingerbread with different ratios of non-traditional types of flour and protein concentrates.

For this purpose the following types of flour were chosen as the main raw material: amaranth, rice, buckwheat and corn, used in the control of celiac disease, a multifactorial disease that disrupts digestion caused by damage to villi in the small intestine by certain foods containing certain proteins: gluten (gluten) and close to it proteins of cereals (avenin, hordein, etc.) [6]-[8]; linseed flour, sesame, pumpkin seeds and milk thistle seeds served as protein concentrates.
The samples were sent to determine organoleptic quality indicators: taste, aroma, color, shape, appearance in the fracture.

The data was processed using the hierarchy analysis method of T. Saaty using the developed model for the effective evaluation of food quality indicators.

\section{RESULTS AND DISCUSSION}

To develop a methodology for predicting the quality of food products, authors analyzed methods that are used to solve similar problems in adjacent areas.

The quality of food products is always evaluated by some determining indicator. Since the degree of significance of the individual quality indicators is not the same, a weight coefficient is introduced [9].

Thus, the quality assessment is related to the task of quantitative evaluation by constructing its complex indicator. There is a dynamic, hierarchical, value and quantitative approaches [10].

As a result, the authors used the hierarchy analysis method to assess the organoleptic quality indicators of flour confectionery products.

The top of the hierarchy is the main goal. Elements of the lower level are many options for achieving the goal. Elements of intermediate levels meet the criteria or factors that connect the goal with the alternative. Having built a food system as a hierarchy, it is necessary to determine the priorities of all the nodes [11].

Priorities are the relative weights of the elements in each group. Like probabilities, priorities are dimensionless quantities that can take values from 0 to 1 . The higher the priority value, the more significant is the element corresponding to it.

$\mathrm{K}_{0}$ - complex upper-level indicator; $\mathrm{K}_{1}$ - chemical composition; $\mathrm{K}_{2}$ - organoleptic characteristics; $\mathrm{K}_{3}$ - physical and chemical properties; $\mathrm{K}_{4}$ - safety indicators; $\mathrm{K}_{5}$ microbiological indicators; $\mathrm{K}_{6}$ - cost price; $\mathrm{K}_{11}$ - protein content; $\mathrm{K}_{12}$ - fat content; $\mathrm{K}_{13}$ - carbohydrate content; $\mathrm{K}_{14}$ mineral content; $\mathrm{K}_{15}$ - vitamin content; $\mathrm{K}_{16}$ - energy value; $\mathrm{K}_{21}$ - taste; $\mathrm{K}_{22}$ - aroma; $\mathrm{K}_{23}$ - colour; $\mathrm{K}_{24}$ - form; $\mathrm{K}_{25}$ - appearance in the fracture; $\mathrm{K}_{31}$ - humidity; $\mathrm{K}_{32}$ - acidity; $\mathrm{K}_{33}$ - porosity; $\mathrm{K}_{34}$ - specific volume; $\mathrm{K}_{35}$ - deformation of crumb compression; $\mathrm{K}_{41}$ - pesticides; $\mathrm{K}_{42}$ - radionuclides; $\mathrm{K}_{43}$ - toxic elements; $\mathrm{K}_{44}$ mycotoxins; $\mathrm{K}_{51}$ - content of the number of mesophilic aerobic and facultative anaerobic microorganisms (NMAFAnM); $\mathrm{K}_{52}$ content of the colibacillus group bacteria (CGB); $\mathrm{K}_{53}$ - content of $S$. aureus; $\mathrm{K}_{54}$ - content of Proterus bacteria; $\mathrm{K}_{55}$ - content of pathogenic. incl. Salmonella; $\mathrm{K}_{56}$ - the content of mold; $\mathrm{K}_{61}$ - cost more than $50 \%$ higher than the average cost of analogue of this product is not a functional purpose; $\mathrm{K}_{62}$ - the cost price is not more than $50 \%$ higher than the average cost price for the analogue of this product is not a functional purpose; $\mathrm{K}_{63}$ prime cost as in the analogue. $\mathrm{K}_{64}$ - cost of not more than $50 \%$ of the lower average cost of the analogue of this product is not functional; $\mathrm{K}_{65}$ - cost more than $50 \%$ of the lower cost of the analogue of this product is not functional; $\mathrm{K}_{111}$ - the content of 
essential amino acids; $\mathrm{K}_{112}$ - the content of interchangeable amino acids; $\mathrm{K}_{121}$ - content of SFA; $\mathrm{K}_{122}$ - content of LSFA; $\mathrm{K}_{123}$ - content of PUFA; $\mathrm{K}_{131}$ - the content of digestible carbohydrates; $\mathrm{K}_{132}$ - the content of dietary fiber; $\mathrm{K}_{141}$ - the content of water-soluble vitamins; $\mathrm{K}_{142}$ - the content of fatsoluble vitamins; $\mathrm{K}_{151}$ - the content of macroelements; $\mathrm{K}_{152}$ the content of trace elements (Fe-iron); $\mathrm{K}_{1111}$ - the amino acid content of lysine (Lys); $\mathrm{K}_{1112}$ - the amino acid content of methionine + cystine (Met + Cys); $\mathrm{K}_{1113}$ - the amino acid content of tryptophan (Trp); $\mathrm{K}_{1114}$ - the amino acid content of isoleucine (Ile); $\mathrm{K}_{1115}$ - the amino acid valine (Val); $\mathrm{K}_{1116}$ amino acid content of phenylalanine + tyrosine (Phe $+\mathrm{Tyr})$; $\mathrm{K}_{1117}$ - amino acid content of threonine (Thr); $\mathrm{K}_{1118}$ - amino acid content of leucine (Leu); $\mathrm{K}_{1411}$ - vitamin B1 (thiamine) content; $\mathrm{K}_{1412}$ - vitamin $\mathrm{B} 2$ (riboflavin) content; $\mathrm{K}_{1413}$ vitamin PP content (niacin. nicotinic acid); $\mathrm{K}_{1421}$ - vitamin $\mathrm{E}$ content; $\mathrm{K}_{1422}$ - $\beta$-carotene content; $\mathrm{K}_{1511}$ - the content of calcium $(\mathrm{Ca}) ; \mathrm{K}_{1512}$ - the content of magnesium $(\mathrm{Mg}) ; \mathrm{K}_{1513}$ the content of phosphorus $(\mathrm{P})$.

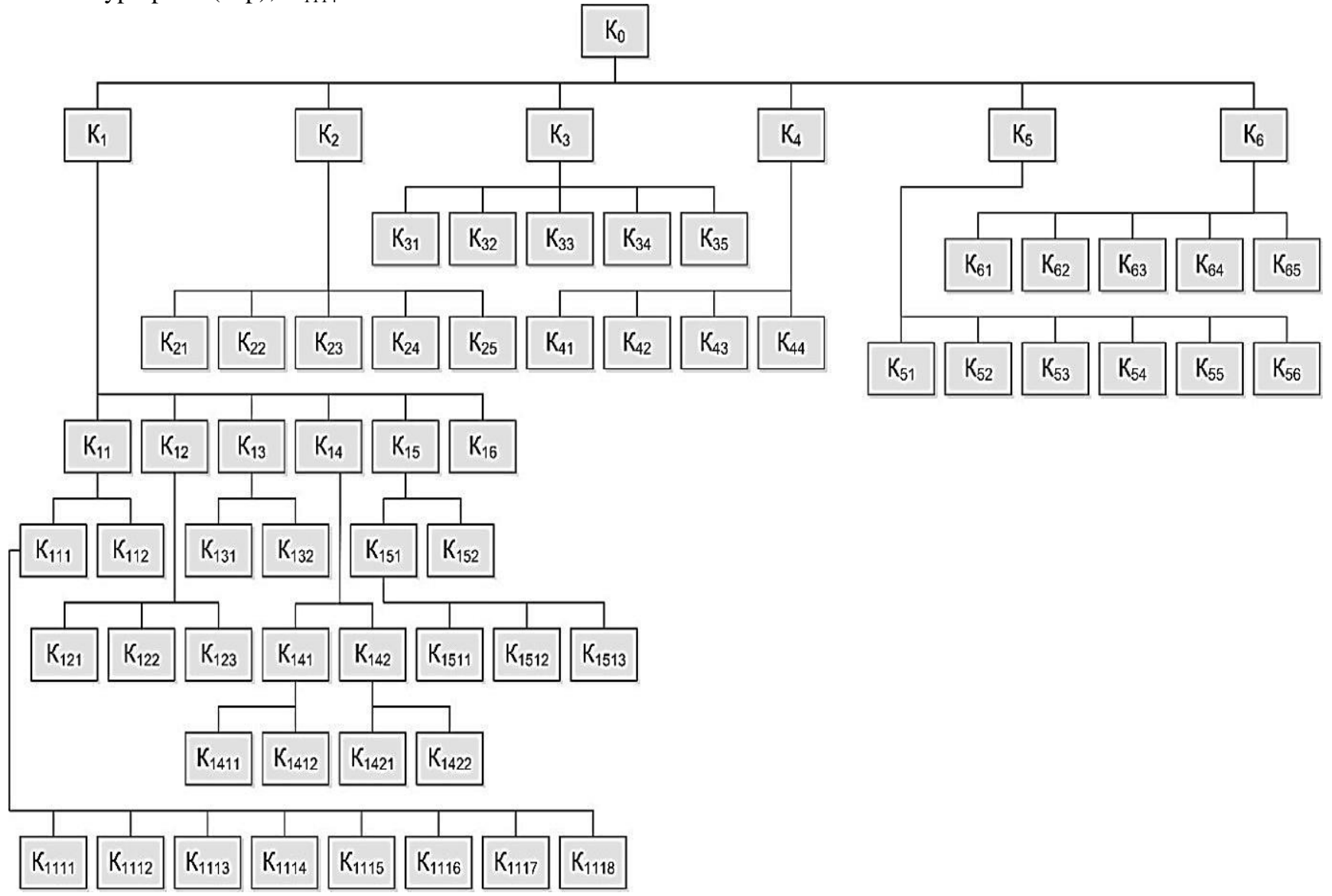

Fig. 1. Multi-level structure of a complex indicator of the quality of a food product (on the example of a bakery product).

IV. CONSTRUCTION OF A MATRIX OF RELATIONS BETWEEN ALTERNATIVE SOLUTIONS OF OBJECTS ON THE EXAMPLE OF GLUTEN-FREE GINGERBREAD

Authors of the article suggest using the hierarchy analysis method (or the Saaty method) [12] to study the weight of each individual parameter in assessing the quality of a food product. The founder of the decision-making process Analytic Hierarchy Process (AHP), known in Russia as a "hierarchy analysis method", is the American scientist T. Saaty from the University of Pittsburg (www.pitt.edu) (www.business.pitt.edu/katz/faculty/saaty.php) [13]-[17].

The method developed by the American mathematician T. Saaty is a more justified means of solving multicriteria problems in a complex situation with hierarchical structures involving both tangible and intangible factors than approaches based on linear logic. As T. Saati said [18], the hierarchy analysis method is a closed logical construction that provides, through simple rules, the analysis of complex problems in all their diversity and leading to the best answer. In addition, the application of the method makes it possible to include in the hierarchy all the knowledge and imagination available to the researcher on the problem under consideration. This, from the authors' point of view, is a balanced way of solving a difficult problem: leaving the math simple and letting the structure's diversity carry the burden of complexity.

AHP is based on paired comparisons of alternatives according to various criteria using a 5-point scale and the subsequent ranking of a set of alternatives according to all criteria and objectives. The relationship between the criteria is taken into account by constructing a hierarchy of criteria and applying the pairwise comparison method to identify the importance of criteria and subcriteria (Fig. 2). 


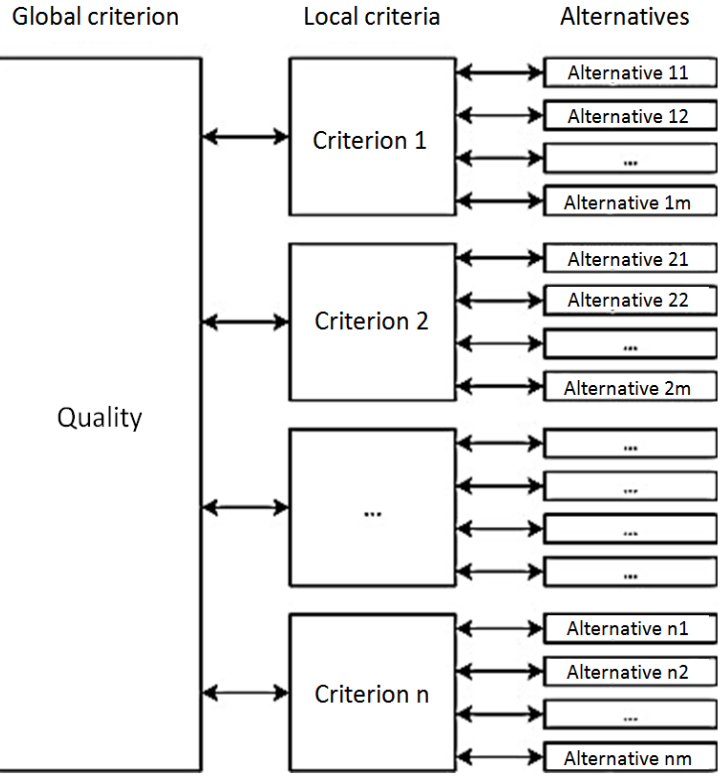

Fig. 2. The scheme of multi-criteria choice with the simplest hierarchy.

To implement the selection algorithm it is sufficient to have information about the type of relationship between each pair of objects and in particular about the existence of strict preference relations between two objects. To do this a relationship variable (1) is introduced

$$
a_{i j}=\left\{\begin{array}{l}
1, \text { if } i-t h \text { variant is equal to } j-t h \\
3, \text { if } i-t h \text { variant moderately exceeds } j-t h \\
5, \text { if } i-t h \text { variant is more significan than } j-t h
\end{array}\right.
$$

Values 2, 4 at the T. Saaty scale are intermediate values between adjacent values of the scale.

On the basis of the data obtained a square matrix $\|a\|$ (Table I) is constructed for the relationship between the alternatives of solutions $a_{j i}=\frac{1}{a_{i j}}, a_{i i}=1 \quad i, j=\overline{1, n}$.

TABLE I. THE MATRIX OF RELATIONSHIP BETWEEN ALTERNATIVE SOLUTIONS (ON THE EXAMPLE OF ORGANOLEPTIC INDICATORS OF GLUTENFREE GINGERBREAD)

\begin{tabular}{|l|l|l|l|l|l|}
\hline $\boldsymbol{a}_{i j}$ & Taste & Aroma & Colour & Form & $\begin{array}{l}\text { View } \\
\text { of the } \\
\text { fracture }\end{array}$ \\
\hline Taste & 1 & 4 & 2 & 5 & 3 \\
\hline Aroma & $1 / 4$ & 1 & 2 & 3 & 2 \\
\hline Colour & $1 / 2$ & $1 / 2$ & 1 & $1 / 3$ & $1 / 4$ \\
\hline Form & $1 / 5$ & $1 / 3$ & 3 & 1 & $1 / 3$ \\
\hline $\begin{array}{l}\text { View of the } \\
\text { fracture }\end{array}$ & $1 / 3$ & $1 / 2$ & 4 & 3 & 1 \\
\hline $\begin{array}{l}\text { Main vector } \\
X_{j}=\sum_{i=1}^{n} a_{i j}\end{array}$ & 2.2833 & 6.3333 & 12.0000 & 12.3333 & 6.5833 \\
\hline
\end{tabular}

\section{DEVELOPMENT OF GLUTEN-FreE CUSTARD CAKE}

\section{RECIPES BASED ON NON-TRADITIONAL RAW MATERIALS}

For example, in the article the calculation of the weight coefficients of one of the criteria (organoleptic characteristic) in the assessment of the quality of model gluten-free custard cakes is given.

The custard cakes belong to the group of confectionery products and are one of the components of the diet of the population. However in diseases associated with hereditary genesis, which includes celiac disease (gluten enteropathy), not everyone can eat foods containing wheat flour [19]. Foods that do not contain gluten make one of the segments of the fast-growing market of specialized food products. The assortment of bakery and flour confectionery products for the gluten-free diet is constantly expanding. As gluten-free raw materials, starch-containing raw materials are most often used. It reduces nutritional value and gives the products worse organoleptic properties than traditional assortment [20]-[22].

Scientists of the "Technology of grain processing, bakery, macaroni and confectionery production" chair from the Razymovsky MSUTM (FCU) developed recipes for glutenfree custard cakes based on unconventional raw materials amaranth, rice, buckwheat, corn, linseed, sesame, pumpkin seed flour and milk thistle seed flour. Each sample was assigned a serial number (Table II). The resulting gingerbread was analyzed for organoleptic characteristics (taste, aroma, color, shape and appearance in the fracture) using the hierarchy analysis method of the above mentioned algorithm.

Table I presents a weighted average of respondents' preferences in the choice of flour confectionery products (gluten-free custard cakes). For the reliability of the results of the assessment the number of respondents was 7 people [23].

The vector of priorities was calculated from the matrix $\|a\|$ - According to mathematical terms this is the main eigenvector, which after normalization becomes a vector of priorities. To calculate the analytical estimate of a given vector there are several ways. One of them is as follows. We find the sum of the columns $X_{j}=\sum_{i=1}^{n} a_{i j}, j=\overline{1, n}$ of the matrix $\|a\|$ in the form of a row vector $\{2.2833 ; 6.3333 ; 12.0000$; $12.3333 ; 6.5833\}$ and divide each column element by this sum. As a result we get a new matrix $\|a *\|$ of values (Table III), which allows us to evaluate the significance of each individual indicator in the overall product perception characteristic.

Finding the average value of each $i$-line allows you to get the column vector of priorities $\{0.419 ; 0.196 ; 0.089 ; 0.104$; $0.191\}$.

Thus, according to this expert ranking of the priorities between the indicators of organoleptic evaluation we obtain that the highest weight coefficient has "taste" - 41.9\%, then the "aroma" $-19.6 \%$, then the "fracture" in $19.1 \%$, the "form" $-10.4 \%$, the "color" $-8.9 \%$. 
TABLE II. COMPOSITION OF FLOUR COMPOSITE MIXTURES FOR GLUTENFREE GINGERBREAD, \%

\begin{tabular}{|l|l|l|l|l|l|l|l|l|l|}
\hline \multirow{2}{*}{ Sample Name } & \multicolumn{9}{|l|}{ Sample number } \\
\cline { 2 - 11 } & 1 & 2 & 3 & 4 & 5 & 6 & 7 & 8 & 9 \\
\hline Rice flour & 60 & 60 & - & 60 & - & 60 & - & - & 70 \\
\hline Amaranth flour & 20 & - & 20 & - & - & 30 & 20 & 30 & 20 \\
\hline Pumpkin seed flour & 20 & 20 & - & 20 & 20 & - & 20 & - & - \\
\hline Buckwheat flour & - & 20 & 60 & - & 60 & - & - & 60 & - \\
\hline Sesame flour & - & - & 20 & - & - & - & - & - & 10 \\
\hline Corn flour & - & - & - & 20 & 20 & - & 60 & - & - \\
\hline $\begin{array}{l}\text { Schrot from the } \\
\text { seeds of milk thistle }\end{array}$ & - & - & - & - & - & 10 & - & - & - \\
\hline Flax, semi-fat flour & - & - & - & - & - & - & - & - & - \\
\hline
\end{tabular}

TABLE III. A NEW MATRIX OF VALUES

\begin{tabular}{|l|l|l|l|l|l|l|}
\hline$a_{i j}$ & Taste & Aroma & Colour & Form & $\begin{array}{l}\text { Vector of } \\
\text { View of } \\
\text { the } \\
\text { fracture } \\
\text { priorities } \\
\sum_{j=1}^{n} a_{i j}\end{array}$ & $X_{i}=\frac{\sum_{j=1}}{n}$ \\
\hline Taste & 0.438 & 0.632 & 0.167 & 0.405 & 0.456 & 0.419 \\
\hline Aroma & 0.109 & 0.158 & 0.167 & 0.243 & 0.304 & 0.196 \\
\hline Colour & 0.219 & 0.079 & 0.083 & 0.027 & 0.038 & 0.089 \\
\hline Form & 0.088 & 0.053 & 0.250 & 0.081 & 0.051 & 0.104 \\
\hline $\begin{array}{l}\text { View of } \\
\text { the } \\
\text { fracture }\end{array}$ & 0.146 & 0.079 & 0.333 & 0.243 & 0.152 & 0.191 \\
\hline
\end{tabular}

The obtained values are used to calculate the generalized complex quality indicator of gingerbread.

VI. INVESTIGATION OF ORGANOLEPTIC QUALITY INDICATORS OF GLUTEN-FREE GINGERBREAD USING THE HIERARCHY ANALYSIS METHOD

After conducting a general assessment of the perception of the food product it is necessary to perform calculations for each individual indicator of the investigated characteristic of the compared samples of gluten-free custard cakes. In our case there are nine samples.

First, respondents rated the indicators of organoleptic evaluation with each other (Table I), and then compared model samples of flour confectionery products against these five characteristics (Table IV).

Table IV presents the average weighted estimates of respondents in a pairwise comparison of nine samples of model flour confectionery products by organoleptic indicators - taste, aroma, color, shape and appearance of the fracture.
TABLE IV. MATRIX OF PAIRWISE COMPARISONS OF FLOUR CONFECTIONERY

a) Taste

\begin{tabular}{|c|c|c|c|c|c|c|c|c|c|}
\hline & - & 节 & 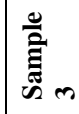 & 节 & م & 。ัّ & م & & \\
\hline Sample 1 & & 1 & $1 / 3$ & $1 / 2$ & $1 / 3$ & $1 / 4$ & $1 / 5$ & $1 / 5$ & $1 / 4$ \\
\hline Sample 2 & & 1 & $1 / 3$ & $1 / 2$ & $1 / 3$ & $1 / 4$ & $1 / 5$ & $1 / 5$ & $1 / 4$ \\
\hline Sample 3 & & 3 & 1 & 2 & 1 & $1 / 2$ & $1 / 3$ & $1 / 3$ & $1 / 2$ \\
\hline Sample 4 & & 2 & $1 / 2$ & 1 & $1 / 2$ & $1 / 3$ & $1 / 4$ & $1 / 4$ & $1 / 3$ \\
\hline Sample 5 & & 3 & 1 & 2 & 1 & $1 / 2$ & $1 / 3$ & $1 / 3$ & $1 / 2$ \\
\hline Sample 6 & & 4 & 2 & 3 & 2 & 1 & $1 / 2$ & $1 / 2$ & 1 \\
\hline \begin{tabular}{|l|} 
Sample 7 \\
\end{tabular} & & 5 & 3 & 4 & 3 & 2 & 1 & 1 & 2 \\
\hline Sample 8 & & 5 & 3 & 4 & 3 & 2 & 1 & 1 & 2 \\
\hline \begin{tabular}{|l|} 
Sample 9 \\
\end{tabular} & & 4 & 2 & 3 & 2 & 1 & $1 / 2$ & $1 / 2$ & 1 \\
\hline Sum & $\begin{array}{l}8 \\
8 \\
8 \\
\infty \\
\text { i }\end{array}$ & $\begin{array}{l}8 \\
8 \\
8 \\
\infty \\
\dot{\sim}\end{array}$ & $\frac{\sqrt{0}}{\frac{0}{2}}$ & $\begin{array}{l}8 \\
8 \\
8 \\
\stackrel{\sim}{0}\end{array}$ & $\begin{array}{l}\hat{0} \\
\stackrel{0}{0} \\
\dot{m}\end{array}$ & $\underset{m}{m}$ & $\frac{\hat{\sigma}}{\tilde{r}}$ & $\frac{\hat{\sigma}}{\stackrel{m}{+}}$ & $\begin{array}{c}\text { ले } \\
\stackrel{\infty}{r}\end{array}$ \\
\hline
\end{tabular}

b) Aroma

\begin{tabular}{|c|c|c|c|c|c|c|c|c|c|}
\hline & 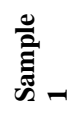 & 节 & م & 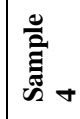 & م泀 & ص & م & 节 & \\
\hline Sample 1 & & 1 & $1 / 3$ & $1 / 2$ & $1 / 3$ & $1 / 4$ & $1 / 5$ & $1 / 5$ & $1 / 4$ \\
\hline \begin{tabular}{|l|} 
Sample 2 \\
\end{tabular} & & 1 & $1 / 3$ & $1 / 2$ & $1 / 3$ & $1 / 4$ & $1 / 5$ & $1 / 5$ & $1 / 4$ \\
\hline Sample 3. & & 3 & 1 & 2 & 1 & $1 / 2$ & $1 / 3$ & $1 / 3$ & $1 / 2$ \\
\hline Sample 4 & & 2 & $1 / 2$ & 1 & $1 / 2$ & $1 / 3$ & $1 / 4$ & $1 / 4$ & $1 / 3$ \\
\hline Sample 5 & & 3 & 1 & 2 & 1 & $1 / 2$ & $1 / 3$ & $1 / 3$ & $1 / 2$ \\
\hline Sample 6 & & 4 & 2 & 3 & 2 & 1 & $1 / 2$ & $1 / 2$ & 1 \\
\hline \begin{tabular}{|l|} 
Sample 7 \\
\end{tabular} & & 5 & 3 & 4 & 3 & 2 & 1 & 1 & 2 \\
\hline Sample 8 & & 5 & 3 & 4 & 3 & 2 & 1 & 1 & 2 \\
\hline \begin{tabular}{|l|} 
Sample 9 \\
\end{tabular} & & 4 & 2 & 3 & 2 & 1 & $1 / 2$ & $1 / 2$ & 1 \\
\hline Sum & $\begin{array}{l}8 \\
\delta \\
0 \\
\infty \\
i\end{array}$ & 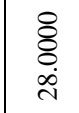 & $\frac{\sqrt{0}}{\stackrel{0}{-}}$ & $\begin{array}{l}8 \\
8 \\
8 \\
\stackrel{1}{~}\end{array}$ & $\begin{array}{l}\hat{8} \\
\stackrel{1}{-}\end{array}$ & 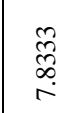 & $\underset{\tilde{\sigma}}{\tilde{\sigma}}$ & 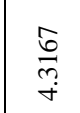 & $\begin{array}{c}\text { mે } \\
\stackrel{\infty}{r}\end{array}$ \\
\hline
\end{tabular}

c) Colour

\begin{tabular}{|c|c|c|c|c|c|c|c|c|c|}
\hline & - & 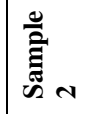 & 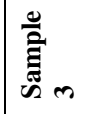 & 范 & م & 。 & 苑 & م & م \\
\hline Sample 1 & & 1 & $1 / 2$ & $1 / 2$ & $1 / 2$ & 1 & $1 / 2$ & $1 / 2$ & 1 \\
\hline Sample 2 & & 1 & $1 / 2$ & $1 / 2$ & $1 / 2$ & 1 & $1 / 2$ & $1 / 2$ & 1 \\
\hline Sample 3 & & 2 & 1 & 1 & 1 & 2 & 1 & 1 & 2 \\
\hline Sample 4 & & 2 & 1 & 1 & 1 & 2 & 1 & 1 & 2 \\
\hline Sample 5 & & 2 & 1 & 1 & 1 & 2 & 1 & 1 & 2 \\
\hline Sample 6 & & 1 & $1 / 2$ & $1 / 2$ & $1 / 2$ & 1 & $1 / 2$ & $1 / 2$ & 1 \\
\hline Sample 7 & & 2 & 1 & 1 & 1 & 2 & 1 & 1 & 2 \\
\hline Sample 8 & & 2 & 1 & 1 & 1 & 2 & 1 & 1 & 2 \\
\hline Sample 9 & & 1 & $1 / 2$ & $1 / 2$ & $1 / 2$ & 1 & $1 / 2$ & $1 / 2$ & 1 \\
\hline Sum & $\begin{array}{l}8 \\
8 \\
\vdots \\
\dot{ \pm}\end{array}$ & $\begin{array}{l}8 \\
8 \\
\dot{\Xi}\end{array}$ & 豙 & $\begin{array}{l}8 \\
8 \\
8\end{array}$ & $\underset{8}{8}$ & $\begin{array}{l}8 \\
\delta \\
\dot{ \pm} \\
\dot{J}\end{array}$ & $\begin{array}{l}8 \\
8 \\
8 \\
\end{array}$ & $\underset{r}{8}$ & $\begin{array}{l}8 \\
\delta \\
\dot{\Xi}\end{array}$ \\
\hline
\end{tabular}


d) Form

\begin{tabular}{|c|c|c|c|c|c|c|c|c|c|}
\hline & 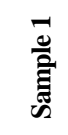 & 苍 & 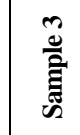 & 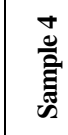 & 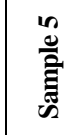 & 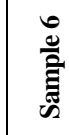 & 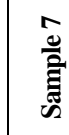 & 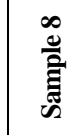 & \\
\hline Sample 1 & 1 & 2 & 1 & 1 & $1 / 2$ & 1 & 1 & $1 / 3$ & $1 / 2$ \\
\hline Sample 2 & $1 / 2$ & 1 & $1 / 2$ & $1 / 2$ & $1 / 4$ & $1 / 2$ & $1 / 2$ & $1 / 5$ & $1 / 4$ \\
\hline Sample 3 & 1 & 2 & 1 & 1 & $1 / 2$ & 1 & 1 & $1 / 3$ & $1 / 2$ \\
\hline Sample 4 & 1 & 2 & 1 & 1 & $1 / 2$ & 1 & 1 & $1 / 3$ & $1 / 2$ \\
\hline Sample 5 & 2 & 4 & 2 & 2 & 1 & 2 & 2 & $1 / 2$ & 1 \\
\hline Sample 6 & 1 & 2 & 1 & 1 & $1 / 2$ & 1 & 1 & $1 / 3$ & $1 / 2$ \\
\hline Sample 7 & 1 & 2 & 1 & 1 & $1 / 2$ & 1 & 1 & $1 / 3$ & $1 / 2$ \\
\hline Sample 8 & & 5 & 3 & 3 & 2 & 3 & 3 & 1 & 2 \\
\hline Sample 9 & & 4 & 2 & 2 & 1 & 2 & 2 & $1 / 2$ & 1 \\
\hline Sum & $\begin{array}{l}8 \\
8 \\
n \\
i \\
\end{array}$ & 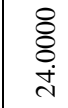 & $\begin{array}{l}8 \\
8 \\
n \\
\end{array}$ & $\begin{array}{l}8 \\
8 \\
n \\
i \\
\end{array}$ & $\frac{8}{n}$ & $\begin{array}{l}8 \\
8 \\
n \\
i \\
\end{array}$ & $\begin{array}{l}8 \\
\delta \\
n \\
i \\
\end{array}$ & $\begin{array}{l}\hat{0} \\
\infty \\
\dot{\infty} \\
\dot{m}\end{array}$ & $\begin{array}{l}8 \\
\frac{1}{6} \\
0\end{array}$ \\
\hline
\end{tabular}

e) View of the fracture

\begin{tabular}{|c|c|c|c|c|c|c|c|c|c|}
\hline & & 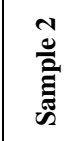 & m & 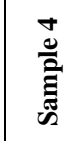 & 㣢 & 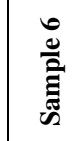 & 氖 & 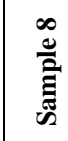 & 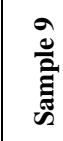 \\
\hline Sample 1 & & 1 & 1 & 1 & 2 & 1 & $1 / 2$ & 1 & 1 \\
\hline Sample 2 & 1 & 1 & 1 & 1 & 2 & 1 & $1 / 2$ & 1 & 1 \\
\hline Sample 3 & 1 & 1 & 1 & 1 & 2 & 1 & $1 / 2$ & 1 & 1 \\
\hline Sample 4 & 1 & 1 & 1 & 1 & 2 & 1 & $1 / 2$ & 1 & 1 \\
\hline Sample 5 & $1 / 2$ & $1 / 2$ & $1 / 2$ & $1 / 2$ & 1 & $1 / 2$ & $1 / 3$ & $1 / 2$ & $1 / 2$ \\
\hline Sample 6 & & 1 & 1 & 1 & 2 & 1 & $1 / 2$ & 1 & 1 \\
\hline Sample 7 & & 2 & 2 & 2 & 3 & 2 & 1 & 2 & 2 \\
\hline Sample 8 & & 2 & 2 & 2 & 3 & 2 & 1 & 2 & 2 \\
\hline Sample 9| & 1 & 1 & 1 & 1 & 2 & 1 & $1 / 2$ & 1 & 1 \\
\hline Sum & $\begin{array}{l}8 \\
8 \\
n \\
0\end{array}$ & $\begin{array}{l}8 \\
8 \\
n ! \\
0\end{array}$ & $\begin{array}{l}8 \\
8 \\
n \\
0\end{array}$ & $\begin{array}{l}8 \\
8 \\
n \\
0\end{array}$ & $\begin{array}{l}8 \\
8 \\
\stackrel{0}{0}\end{array}$ & $\begin{array}{l}8 \\
8 \\
n \\
0\end{array}$ & $\begin{array}{c}m \\
m \\
m \\
n\end{array}$ & $\begin{array}{l}8 \\
8 \\
n \\
0\end{array}$ & $\begin{array}{l}8 \\
\delta \\
n \\
0\end{array}$ \\
\hline
\end{tabular}

The calculation of the priority vector (taste, aroma, color, shape and appearance of the fracture) of nine model samples of gluten-free custard cakes is presented in Table $\mathrm{V}$ and is obtained similarly to the one discussed above.

As a result we obtained a matrix of weight coefficients for each index of organoleptic evaluation (Table VI).

Multiplying the matrix of weight coefficients (Table VI) by the priority column vector (Table II) we obtain the weights of alternatives (gingerbread) $\{0.0538 ; 0.0497 ; 0.0906 ; 0.0715$; $0.0899 ; 0.1169 ; 0.1925 ; 0.2104 ; 0.1247\}$ in terms of preferences of respondents.
TABLE V. COMPARISON OF MODEL GLUTEN-FrEE GINGERBREAD WITH RESPECT TO FIVE ORGANOLEPTIC PARAMETERS

a) Taste

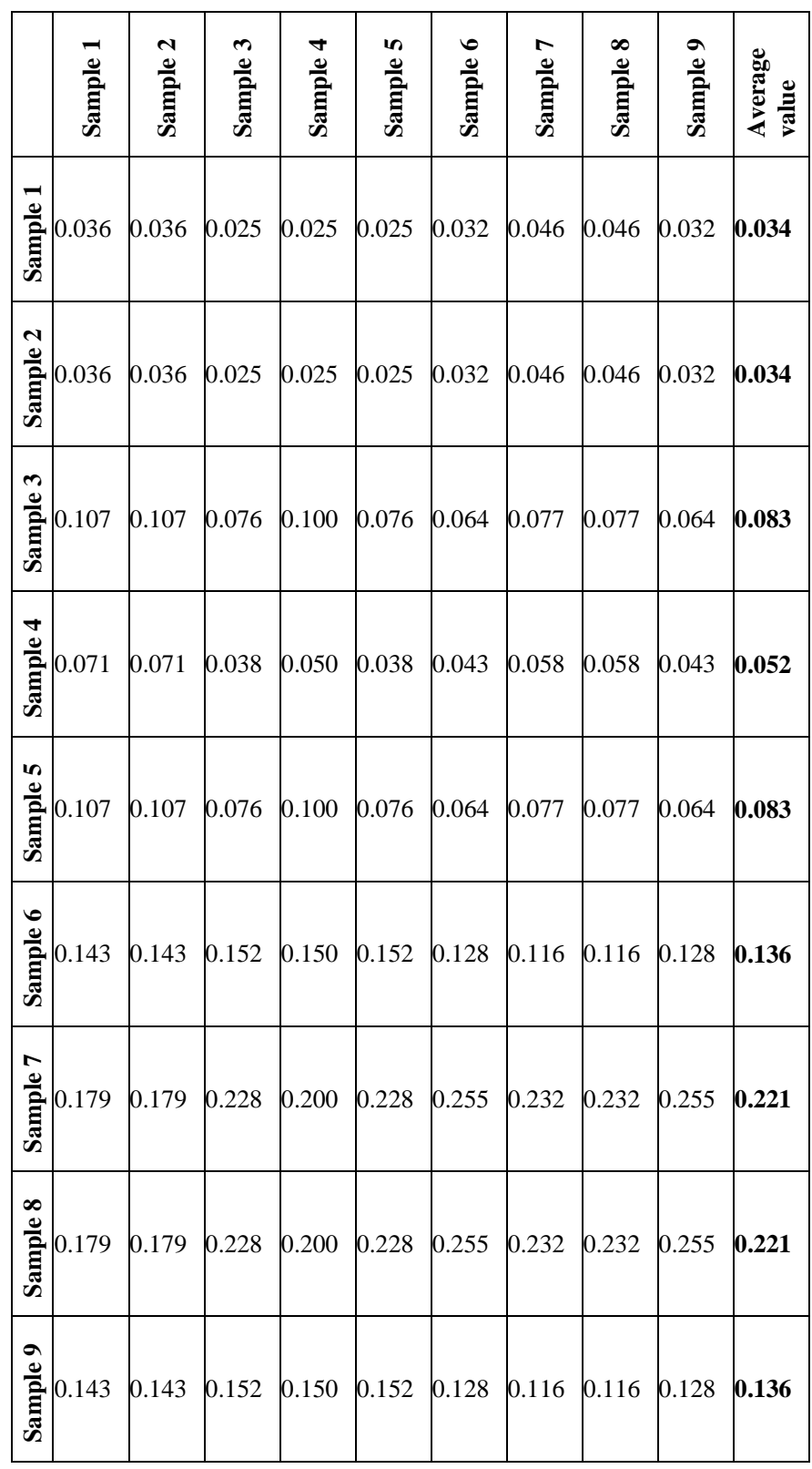

b) Aroma

\begin{tabular}{|c|c|c|c|c|c|c|c|c|c|c|}
\hline & & 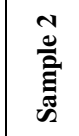 & 芯 & & 恼 & 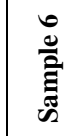 & & 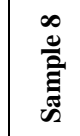 & & 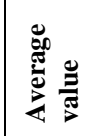 \\
\hline 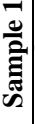 & 0.036 & 0.036 & 0.025 & 0.025 & 0.025 & 0.032 & 0.046 & 0.046 & 0.032 & 0.034 \\
\hline 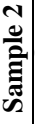 & 0.036 & 0.036 & 0.025 & 0.025 & 0.025 & 0.032 & 0.046 & 0.046 & 0.032 & 0.034 \\
\hline
\end{tabular}



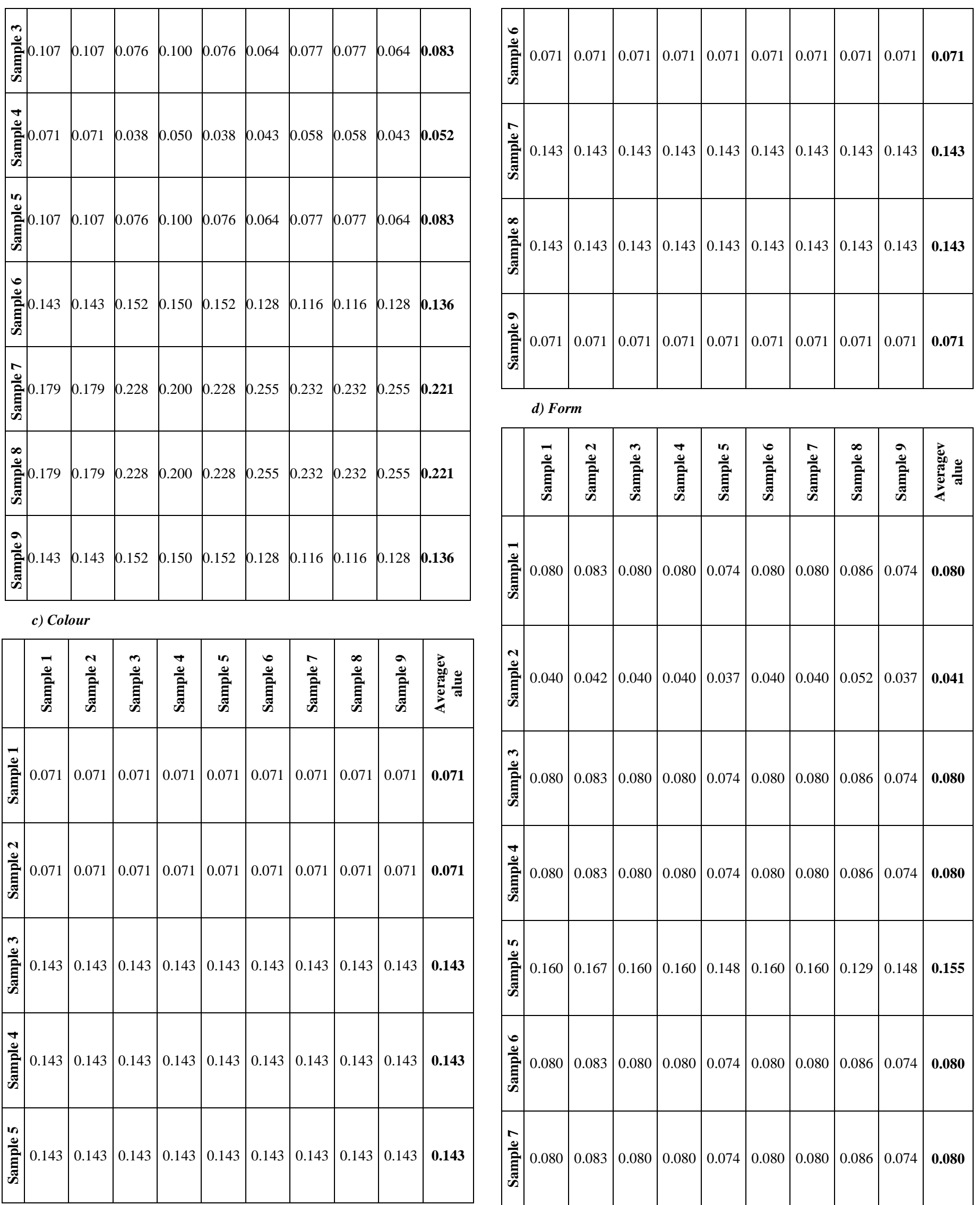

d) Form

\begin{tabular}{|c|c|c|c|c|c|c|c|c|c|c|}
\hline & 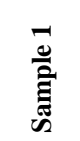 & & 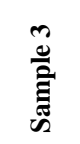 & 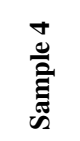 & 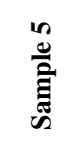 & 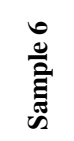 & 焉 & 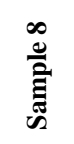 & 产 & 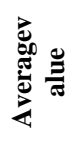 \\
\hline 氙 & 0.080 & 0.083 & 0.080 & 0.080 & 0.074 & 0.080 & 0.080 & 0.086 & 0.074 & 0.080 \\
\hline & 0.040 & 0.042 & 0.040 & 0.040 & 0.037 & 0.040 & 0.040 & 0.052 & 0.037 & 0.041 \\
\hline 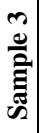 & 0.080 & 0.083 & 0.080 & 0.080 & 0.074 & 0.080 & 0.080 & 0.086 & 0.074 & 0.080 \\
\hline 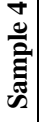 & 0.080 & 0.083 & 0.080 & 0.080 & 0.074 & 0.080 & 0.080 & 0.086 & 0.074 & 0.080 \\
\hline 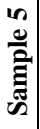 & 0.160 & 0.167 & 0.160 & 0.160 & 0.148 & 0.160 & 0.160 & 0.129 & 0.148 & 0.155 \\
\hline 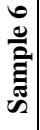 & 0.080 & 0.083 & 0.080 & 0.080 & 0.074 & 0.080 & 0.080 & 0.086 & 0.074 & $\mathbf{0 . 0 8 0}$ \\
\hline 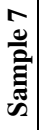 & 0.080 & 0.083 & 0.080 & 0.080 & 0.074 & 0.080 & 0.080 & 0.086 & 0.074 & 0.080 \\
\hline
\end{tabular}




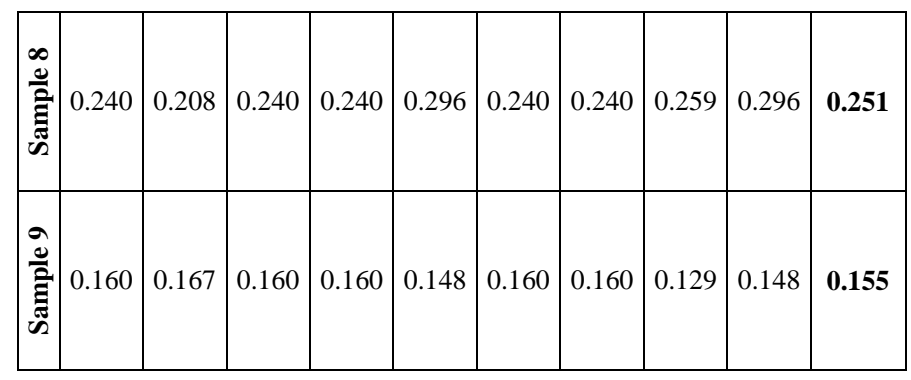

e) View of the fracture

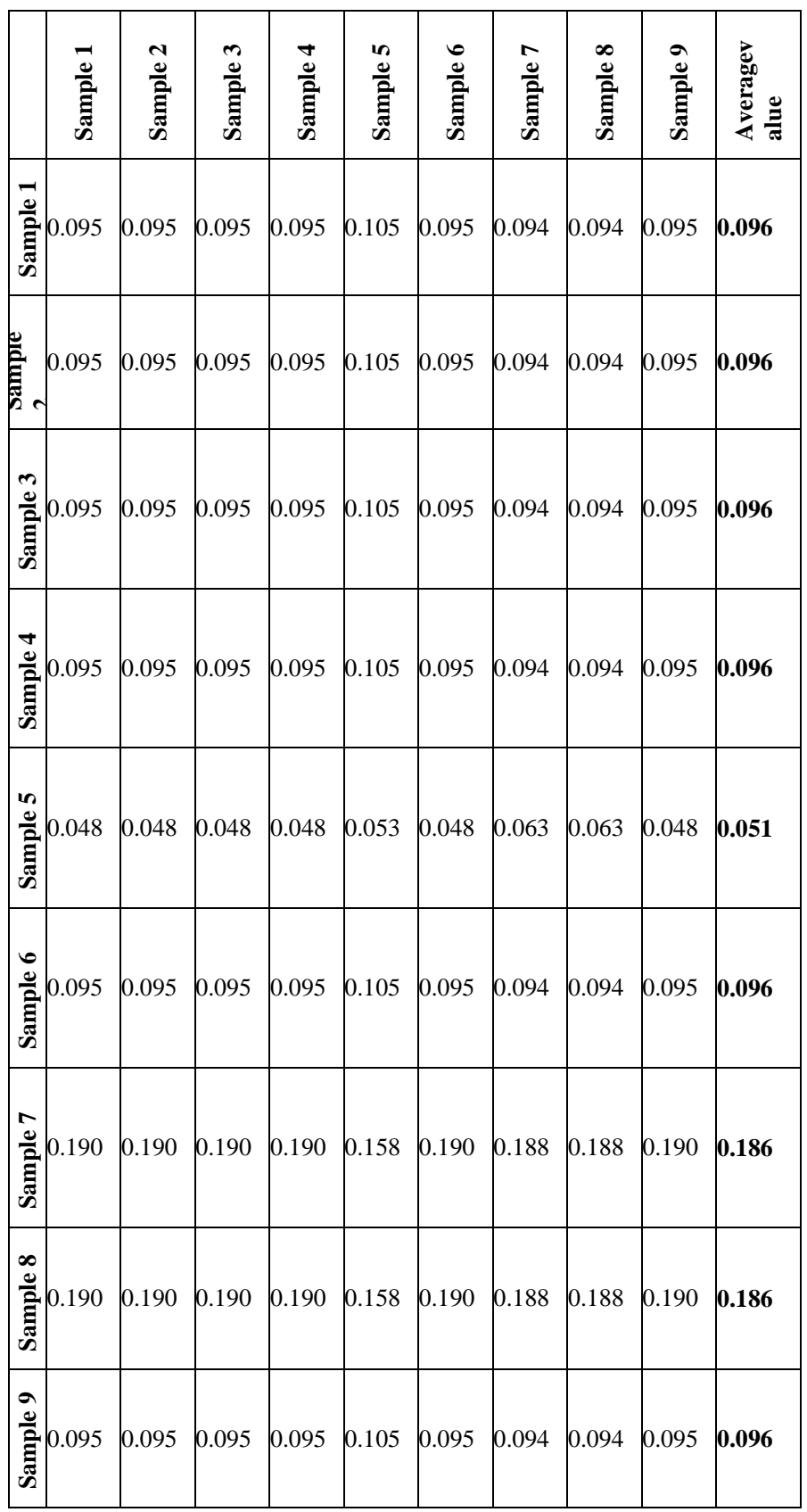

TABLE VI. COMPARISON OF THE ORGANOLEPTIC CHARACTERISTICS OF NINE MODEL FLOUR CONFECTIONERY PRODUCTS

\begin{tabular}{|l|l|l|l|l|l|}
\hline & Taste & Aroma & Colour & Form & $\begin{array}{l}\text { View } \\
\text { of the } \\
\text { fracture }\end{array}$ \\
\hline Sample 1 & 0.034 & 0.034 & 0.071 & 0.080 & 0.096 \\
\hline Sample 2 & 0.034 & 0.034 & 0.071 & 0.041 & 0.096 \\
\hline Sample 3 & 0.083 & 0.083 & 0.143 & 0.080 & 0.096 \\
\hline Sample 4 & 0.052 & 0.052 & 0.143 & 0.080 & 0.096 \\
\hline Sample 5 & 0.083 & 0.083 & 0.143 & 0.155 & 0.051 \\
\hline Sample 6 & 0.136 & 0.136 & 0.071 & 0.080 & 0.096 \\
\hline Sample 7 & 0.221 & 0.221 & 0.143 & 0.080 & 0.186 \\
\hline Sample 8 & 0.221 & 0.221 & 0.143 & 0.251 & 0.186 \\
\hline Sample 9 & 0.136 & 0.136 & 0.071 & 0.155 & 0.096 \\
\hline
\end{tabular}

Thus, according to experts' opinions on organoleptic indicators the first place has the 8-th sample.

Having ranked the samples of gluten-free gingerbread we get the following ranks:

1 place - sample 8

2 place - sample 7

3 place - sample 9

4 place - sample 6

5 place - sample 3

6 place - sample 5

7 place - sample 4

8 place - sample 1

9 place - sample 2 .

\section{CONCLUSION}

Thus, the best organoleptic properties got the gingerbread, which includes buckwheat flour, amaranth and linseed semifat in the ratio of 60:30:10, and the worst - a gingerbread based on rice flour, buckwheat and pumpkin seeds in a ratio of 60:20:20.

The results obtained correlate with the data obtained in the tasting organoleptic evaluation of samples on a point scale.

The application of mathematical approaches in the processing of expert assessments of the quality of food products on the basis of the hierarchy analysis method gives an objective final result. The constructed hierarchy of the global criterion (of quality) has flexibility. Adding new links to a well-structured hierarchy does not destroy its characteristics. Using the method when choosing alternatives for assessing the quality of food products, it is impossible to skip or ignore the feedbacks and reciprocal links between the components being investigated and the levels of the hierarchy, which minimizes the possibility of making a wrong decision.

\section{REFERENCES}

[1] V.G. Kaishev, S.N. Seregin State and prospects of development of production of functional food products. Meat technologies, 2018. № 2. P. 54-57.

[2] Barsukova N.V., Reshetnikov D.A., Krasilnikov V.N. Food engineering: technologies of gluten-free flour products. Scientific journal of NRU ITMO. A series of "Processes and devices of food production." - 2011 
[3] Nikitin I.A. Theoretical aspects of technology of effective functionality of food products. Collection of materials of the conference "Strengthening the Competitive Potential of Food Enterprises by Developing Effective Biotechnologies". FGANU Research Institute of the Bakery Industry. St. Petersburg Branch, 2016. P. 84-87.

[4] Nikitin I.A., Kulakov V.G., Korovina E.S., Pyreseva A.I. Fragmentary research of the market of functional food products from gluten-free raw materials. Bread products, 2016. No. 11. P. 29-31.

[5] Klokonos M.V., Semenkina N.G. Ways to confirm the functionality of bakery products. New in technics and technology of functional food products based on biomedical views Materials of the VI International Scientific and Technical Conference. Ministry of Education and Science of the Russian Federation. FGBOU VO "Voronezh State University of Engineering Technologies". - 2017. - P. 566-571.

[6] Kuznetsova L.I., Dubrovskaya N.O. Polycomponent mixtures for the production of gluten-free products / Bakery production, 2014. No. 10. P. 20.

[7] Schneider D.V. New program for the formation of recipes for glutenfree products. Bread products. - 2012. - No. 8. - P. 50-52.

[8] Vokhmyanina N.V. The modern idea of celiac disease. S.-Pb .: Triad. $2009-150$ p.

[9] Bazarnova Yu.G., Burova T.E., Marchenko V.I. Biochemical bases of processing and storage of raw materials of animal origin - $\mathrm{SPb} \therefore$ Prospect of Science, 2011. - $192 \mathrm{p}$.

[10] Ivashov V.I., Andreenkov V.V., Solntseva G.L. Qualification of meat and meat products: overview information. - Moscow: AgroNIITEIMMP, 1989. - 48 p.

[11] Nikitina M.A., Zakharov A.N., Shcherbinina E.O. Evaluation of organoleptic quality indices of meat products by statistical methods. Meat industry, 2017. № 5. P. 50-52.

[12] Saaty T.L. Decision making with the analytical hierarchy process // International Journal services sciences, 2008. V.1. no. 1. pp. 83-98. URL: http://www.colorado.edu/geography/leyk/geog_5113/readings/saaty_200 8.pdf (backs 08/08/2017).

[13] T.L. Saaty. On the measurement of the intangible. Approach to relative measurements based on the eigenvector of the matrix of paired comparisons / Cloud of Science. - 2015. -V. 2. No. 1. - P. 5-39.

[14] T.L. Saaty. Decision making with dependencies and feedbacks. Analytical relations. - Moscow: Lenard, 2015. - 360 p.

[15] T.L. Saaty. Decision making with the analytical hierarchy process. 2008. - Vol. 1. - p. 83-98.

[16] T.L. Saaty. The seven pillars of the analytic hierarchy process // In: Multiple criteria decision making in the new millennium. - Berlin: Springer, 2001. - p. 1-15.

[17] T.L. Saaty. Decision-making with the AHP: why is the principal eigenvector necessary // European Journal of Operational Research. 2003. - Vol. 145. - p. 85-91.

[18] Saaty T. Decision-making. The method of analyzing hierarchies. - M .: Radio and Communication, 1993. - 278 p.

[19] Borisenko A.A., Sarycheva L.A., Borisenko A.A. Modeling. development and optimization of healthy food products. Ministry of Education and Science of the Russian Federation. Federal State budget educational institution of higher professional education "North Caucasus State Technical University". Stavropol, 2012. 197 p.

[20] Dubrovskaya N.O., Kuznetsova L.I., Parahina O.I. Production of glutenfree bakery products using non-traditional plant materials / Bread products, 2016. No. 11. P. 36-37.

[21] Kuznetsova L.I., Dubrovskaya N.O., Parakhina O.I. Improving the quality and nutritional value of gluten-free bread. Bakery of Russia, 2015. № 3. P. 19-22.

[22] Chizhikova O.G. Dry mixtures with the addition of sea-buckthorn meal for gluten-free bakery products. Food industry. -2013. -No 3.-P. 18-19.

[23] Klyachkin V.I. Statistical methods in quality management: computer technologies. - Moscow: Finance and Statistics, 2007. - 304 p. 